NBER WORKING PAPER SERIES

LIQUIDITY AND MARKET STRUCTURE

\author{
Sanford J. Grossman \\ Merton H. Miller
}

Working Paper No. 2641

NATIONAL BUREAU OF ECONOMIC RESEARCH 1050 Massachusetts Avenue

Cambridge, MA 02138

July 1988

A paper presented at the Annual Meetings of the American Finance Association, December 29, 1987 in Chicago, Illinois. Helpful comments on an earlier draft were received from Kenneth Cone, Kenneth French, T. Eric Kilcollin, Andrei Shleifer, Lester Telser and Robert Vishny. This research is part of NBER's research program in Financial Markets and Monetary Economics. Any opinions expressed are those of the authors not those of the National Bureau of Economic Research. 
NBER Working Paper \#2641

July 1988

LIQUIDITY AND MARKET STRUCTURE

ABSTRACT

Market liquidity is modelled as being deternined by the demand and supply of immediacy. Exogenous liquidity events coupled with the risk of delayed trade create a demand for immediacy. Market makers supply immediacy by their continuous presence, and willingness to bear risk during the tine period between the arrival of final buyers and sellers. In the long run the number of market makers adjusts to equate the supply and demand for immediacy. This determine the equilibrium level of liquidity in the market. The lower is the autocorrelation in rates of return, the higher is the equilibrius level of liquidity.

Sanford J. Grossman Department of Economics Princeton University Princeton, NJ 08544
Merton H. Miller Department of Economics University of Chicago Chicago, IL 60637 


\section{LIQUIDITY AND MARKET STRUCTURE}

by

Sanford J. Grossman and Merton H. Miller

\section{Introduction}

Keynes once observed that while most of us could surely agree that Queen Victorla was a happler woman, but a less successful monarch than Queen Elizabeth I, we would be hard put to restate that notion in precise mathematical terms. Keynes' observation could apply with equal force to the notion of market liquidity. The $T$-bond Futures pit at the Chicago Board of Trade is surely more liquid than the local market for residential housing. But how much more? What is the decisive difference between them? Is the colorful open-outcry format of the $T$-bond Futures market the source of its great liquidity? Or does the causation run the other way?

Those are some of the issues we propose to consider here. Our purpose is to present a simple model of market structure that captures the essence of market liquidity. A key feature of the model is its finer partitioning of time intervals and of roles for market participants than in standard treatments of the determination of market prices. Much economic theory, in the Walrasian tradition, still proceeds as if prices were set in a gigantic town meeting in which all potential buyers and sellers participate directly. Researchers in the rapidly-growing specialty, sometimes dubbed market microstructure theory, have expanded the cast to include market makers in the sense of intermediaries who can fill gaps arising from imperfect synchronization between the arrivals of the buyers and the sellers. The focus of this literature has been on the inventory management policies of market makers (see, $.8 .$, Stoll $(1978)$ ) and on their responses to the threat 
of adverse Information trading against thed (see, e.g., Glosten and Milgrom (1985)). Our Intention here, however, is not to expand this Important and Interesting class of Inventory models but to flt these Intermediarles and their temporary Inventory holdings Into a larger framework that also encompasses the ultimate demanders and suppliers.

\section{A Brief Overview of the Model. The Supoly and Demand for Immedlacy}

Our model of market structure has 2 particlpant groups and we shall refer to them, for simpliclty, as market makers, and outside customers. For simplicity of exposition only, we shall take their basic tastes, Including risk tolerances, as the same. Thelr roles are defined at this stage principally in terms of their intelal endowments.

Within the group of outside customers are some who, for any of a varlety of reasons, experience what we call a liauldity event, which leads thea to perceive a gap at current prices between thelr deslred holdings of a particular asset and thelr current holdings of that asset. Even if the gaps sum to zero across the whole group, as we assume, some customers might propose to remedy their portfollo imbalance Immedlately by undertaking a transaction in the asset; and for concreteness in exposition, suppose these potential liquidity traders are net sellers. In our model the putative sellers can choose to offer the goods Immedlately to the market makers who happen to be in the market currently and who have no holdings of the asset, or at least no imbalance that they too are seeking to eliminate. Or, a seller can postpone the offer to sell for one stylized period until the potential buyer custoners on the other side of the trade have learned of the offer and have had a chance to come to the market. 
Clearly the seller faces a trade-off. By walting until more potential buyers have been notifled, the seller increases the chance of finding an eager buyer. But this delay carries risks; while the buyers are assembling, the ultimate equilibrium price may shift. The best selling price for a sale delayed to the second perlod may be substantially lower (or higher) than the price in a sale to a market maker in the first period. By selling lmediately, that interia price risk is transferred to the market maker who then walts unt1l the ultimate buyers have assembled. When we speak of the demand for immediacy by a seller, we mean the willingness to sell rather than walt. This demand depends on the volatility of the underlying price and the diversifiability of the risk of an adverse price move.

The warket makers charge for bearing price risk by offering the Impediate sellers a price that is not uncertain, but that is lower, on average, than the sellers could expect fron delaying. The expected price rise between perlods 1 and 2 is, of course, only the market maker's gross return before allowing for the costs of supplying the service. These include any direct costs of effecting and monitoring trades, but also the 1mportant, though often overlooked cost of being avallable and open for business when the outs1de customers arrive to trade. These opportunity costs of maintaining a continuous presence in the market, which we model as fixed costs, play a key role in determining the supply of immedfacy and market making services.

The market makers, as emphasized earlier, must also assume the price risk that the 1mmediacy demanders shed. That the aggregate price risk is merely shifted to the market makers does not, however, rule out efficlency gains from the arrangement. In our model, where all participants have the 
same risk tolerance, the gains arise essentially from diversification.-the spreading of the transferred risks over the entire group of market aakers. The larger that group, the lower, ceteris paribus the risk and expected return per unit traded by each and hence also the lower the effective cost of Immediacy to the customers. The number of market makers will adjust unt1l, In equilibriun, the returns to each from assuming the risk of waiting to trade with the ultimate buyers just balance the costs of aaintaining a continuous presence in the market. This adjustment determines the equilibriun amount of lmmediacy provided, 1.e., the amount by which price is temporarlly depressed by a typical sell order.

Our model thus suggests looking to differences in the cost to market makers of maintaining a market presence and to differences in the demand by customers for Immediacy for the keys to market structure and market liquidity. The greater the demand for immediacy and the lower the cost to market makers of malntaining a continuous presence, the larger the proportion of the transactions between ultimate customers effected initially through market makers, and hence the more liquid the market.

\section{The Lifuldicy Spectrun in Real World Market Structures}

Successful futures markets are the leading examples of markets where the demand for Imediacy is high. Futures markets are successful precisely for those comodities and in those time periods when price volatility, and hence the risks of delaying trading are high. The price risks of volatility are further reinforced for potential hedger custowers in those narkets by the high leverage and extreme under-diversification of the underlying spot Inventory positions that constitute their aain ine of business. Imnediacy also becomes of particular concern where, as is frequently the case, the 
futuras transaction is merely one 1 eg of an Inter-contract or inter-market hedge. Little or no risk may be Incurred once all the components of the hedge have been put in place; but much risk is incurred when only some of the legs have been set. When the transactor is "naked," to use the colorful language of the trade, the delay of even a few seconds can becoue critical. (See, e.g., Grossaan and Miller (1986b).)

The demand for immediacy in successful futures markets is not only urgent, but sustained. The regular seasonal bulld up and build down of Inventories as commodities move through the production chain creates a continual desire to trade, not just to hold futures. In financial futures markets, dealers' inventorles of the underlying securities bulld up and down In response to periodic auctions of U.S. Tressury 1ssues, to the flotation of stocks or bonds by corporations or to the restructuring of portfollos by large institutional investors.

The sustalned demand for hedging and hence for trading futures quickly 1s often accommodated by designating a specific physical market place or exchange in which many competing market makers can offer their services simultaneously. Such arrangements help spread the fixed costs to market makers of maintaining a presence, as does the practice at most present-day futures exchanges of providing trading areas for many different contracts between which Individual market akers can drift as trading interest changes. Many, but not all, futures exchanges also permit market makers to serve both as brokers for customers and as traders on personal account, though not, of course, on the same transaction. Most floor traders tend to specialize in one role or the other, but the freedon to switch roles can permit a quick 
adjustment in the number of market makers when the flow of orders changes abruptly. 1

At the opposite extreme from the highly liquid futures markets where Intermediary market makers particlpate as principals in virtually all transactions, stand the highly 1111 quid markets, such as those for residential housing, where virtually none of the transactions passes through a dealer's temporary inventory. ${ }^{2}$ Sellers of Individual homes are typically less concerned with short-term price volatility, and hence with lmediacy, than with making sure that the widest possible set of ultimate buyers can be Informed of the house's avallabllity. Potential market makers, moreover, face not only all the ordinary costs of maintaining a continuous presence in a thin market, but the additional moral hazards that arise fron the owner's possibly adverse private information about the value of the property. The result is a market in which intermediaries, to the extent that they are Involved at all, provide brokerage or search services, not immediacy.

\section{The Structure of the Stock Market}

Most real-world markets lie somewhere between these liquidity extremes and their structures will typically aix features from both the search markets and the liquidity markets. U.S. stock narket institutions, for example,

1 For a discussion of the benefits and the supposed abuses of dual trading on futures exchanges, see Grossaan and Miller (1986b).

2 Although the fraction of potential trades executed immediately by market makers rather than delayed for search is higher for futures exchanges than in virtually any other narket setting, search plays a role even there. A case in point is so-called "sunshine trading" in which pending large and presunably informationless orders by portfollo insurers are publicized in advance throughout the investment comunity with a view to attracting a large inflow of counterparties prepared to take the other side. Whether such sunshine trading violates long-standing regulatory prohibitions against "prearranged trading" is a policy issue currently much in dispute. 
currently involve at least four distinct forms of market organization operating simultaneously, but in different segments of the aarket and with somewhat different immediacy cllenteles:

1. For a few of the most widely held and heavily traded securities. such as IBM or ATST, the aarket at the New York Stock Exchange often approximates the open-outcry plts at the comadity exchanges. These are stocks in which the minute to winute order flow is highly variable relative to the arrival of news about the underlying value of the shares, and for which our model predicts a large number of aarket aakers in equilibrium. The "crowd" for those stocks, though substantially smaller than in the I-bond futures market, is large enough to offer a competitive discipline to the Exchange's franchised "speclalist," who, in these particularly active markets, typically plays more the role of an auctioneer (and a commission collector) than a market maker on personal account.

2. The specialist's role as a market maker assumes greater prominence for the hundreds of smaller, less active stocks, some of which may not even trade as frequently as once a day. In such stocks, our model would not predict an equilibrium with many market aakers. The designation of a specialist by the Exchange, however, does at least guarantee that someone w11l Indeed be maintalning a physical presence in the market, ready to effect a transaction should an order happen to arrive. The potential for abuse of the specialist's monopoly position is mitigated by the same standard crosssubsidization approach long familiar in U.S. public utillty regulation. As a condition for keeping the franchise, specialists on the New York Stock Exchange, for example, are encouraged by the Exchange to l1mit price changes between successive transactions to no more than one tick (normally 12 1/2 
cents per share), using personal Inventory to absorb any temporary Imbalances along the way. This restriction, which is in fact monitored by the Exchange, serves both to IImIt speclallsts profit and to create the appearance of Ilquidicy, though, in practice only for very small transactions. Should a very large order arrive, however, and should it be larger than can be absorbed by the specialist or by any prevlously entered "IImit orders" then resting in the specialist's "book," the market can switch to search mode. The specialist, with the permission of the Exchange, can suspend trading in the stock and Insticute a search for counterparties to the Imbalance, elther elsewhere on the floor of the Exchange or, more 11kely these days, off the floor at the block-trading desks of the investment bankers.

3. These desks are the third, and increasingly the dominant forn of market organlzation for trading common stocks in the U.S., thanks to the concentration of so much corporate stock in a relatively small number of extrenely large pension funds, wutual funds and other institutional holders. Because relatively small portfollo adjustments by these insticutional holders would be far too large to be absorbed by any speclalist firm, the large blocks of single stocks, or sometines whole portfollos are brought to the "upstairs arket" alintained by the investment banking firms. Until recenty at least, the upstairs desks functioned prinarily as a search market. The upstairs traders essentially "shopped the block" anong their custoners, and when a sultable counterparty had been located, and a deal struck, reported the trade to the relevant specialists on the floor of the Exchange. In the process, they picked up on behalf of the initiating side any linit orders on the specialist's book that were transfotwed into market orders by the price change occasloned by the block erade. 
Although search was the InItial, and still rewains the major function of the upstalrs market, the amount of "positioning" and hence of market-making IIquidity, provided by the upstalrs firms has increased substantially in recent years. The shlft s:aces mainly to the highly liquid futures and options index markets which permit the upstalrs firms to hedge their Inventorles while conducting the search for or walting for the other side of the transaction.

4. Finally, at the other end of the spectrum froa the upstalrs, wholesale broker-dealer market lles the retall, dealer market in Over-theCounter stocks, for which, with a few well-known exceptlons, the normal trading interest is typically too small to justify listing even on a reglonal exchange. I The market for such stocks is not a physical exchange floor but a set of computer terminals. When Introduced originally in the 1970's, the computerized NASDAQ market system for OTC stocks offered essentially only a "bulletin board" In which those market makers with access to the syster could enter price quotes. The quotes, though deemed firm for some standard, minimum size trade were essentially advertisements and the actual transactions were not executed automatically, but negotiated between the parties. The market makers in particular stocks, although they did position

${ }^{1}$ Some corporations of substantial size, however, may nevertheless choose to ilst in this market because there are fewer restrictions on size and capital structure (such as a one-share, one-vote rule) than on the NYSE or AMEX. 
small inventories, assumed no obligation to maintain a continuous presence or to smooth price changes between successive transactions. 1

All four forms of market organization for trading comoon stocks, along with those of the Index futures and options markets, were subjected in October 1987 to what seemed to be liquidity events, in our sense, of unprecedented magnitude. We shall return briefly to those events in Section III. First, however, we turn in Section II to set down the detalled structure of our model of market liquidity and a characterization of its equilibriun.

\section{A Formal Model of Market Llouldity}

In this section we present a formal model of the role of market makers in providing immediacy. We focus most of our attention on the consequences of a temporary order imbalance of size 1 in a simple world with only three dates: 1, 2, and 3. At date 1 a liquidity ovent occurs which creates a temporary order imbalance of size 1. Market makers offset this temporary Imbalance by taking trading positions which they hold until date 2 . We denote the nonmarket makers by the term "outside customer" although, in practice, of course, Individuals and firas can play either role at different times. By a temporary order Imbalance we mean an asynchronization of outside

In addition to the four markets so far listed, there may now be as many as six distinct stock markets if one counts the "after-hours" market (which now includes the trading of big-name U.S. stocks on foreign exchanges) and the so-called "Eourth varket" in which large pension funds, especially those following "passive" or indexing strategies, transfer baskets of stocks directly to and frow each other in essentially informationless trades. The futures and options markets in stocks, of course, constitute still another form of stock market at least for the trading if not the holding of stocks. Many European stock markets, where the volumes of trading are still quite suall by U.S. standards, use "batch" or "periodic call" systens rather than any of the continuous trading systens we find here. For a couprehensive survey of trading practices overseas, see thitcomb (1985). 
custoaer trading tiaes; the net trading demand would be zero at the current price if all traders were simultaneously present in the market.

At date 2 , the market makers offset their positions as other outside customers arrive to offset the lmbalance. Thus, the length of time between dete 1 and date 2 is the period of time needed for enough orders of outside customers to arrive at the market to offset the Initial order Imbalance. Date 3 is introduced only as a terminal condition for valuing the securities as of date 2.1

We assume two assets: a risk-free asset called cash (with zero rate of return), and a risky asset. Let $\mathbb{P}_{3}$ be the exogenously given terminal price (or liquidation value) of the risky asset. Assume that public information about $\bar{p}_{3}$ arrives before trade at period 1 and also before trade at period 2. Lat $\dot{x}_{t}$ be the number of units of the asset owned by an outside customer after trade at time $t$, and let $B_{t}$ be that customer's holdings of cash (in dollars). Two interpretations can be given to $\dot{x}_{3}$. In the first, the outside customer is a commercial hedger and the asset is a futures contract. In this case, the hedger's net holding at perlod 3 is $\dot{x}_{3}-\dot{x}_{2}+1$, where 1 1s the number of units of the spot commodity (which may, of course, be a security) owned by the hedger. The hedger's terminal wealth is then

$$
W_{3}-B_{2}+P_{3} \dot{x}_{3}-B_{2}+P_{3} \dot{x}_{2}+1 P_{3} \text {. }
$$

The hedger is using the futures market to offset the spot price $\bar{p}_{3}$ risk of the intelal position. (Note that under thls futures market interpretation. the asset is in zero supply.)

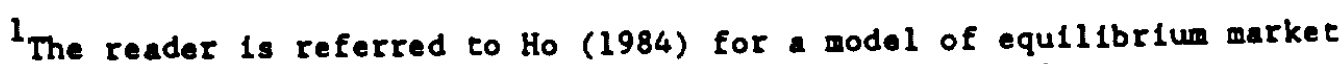
making in a continuous-time, Polsson-arrival-of-orders setting. 
In the second interpretation, the market is a stock market, and the outside customer at time 1 has an endowment of size 1 in the security, which is inappropriate in the light of the customer's risk preferences and Information on the risk-return pattern associated with the security. In this case, $\dot{x}_{3}$ is the final holding of the security at the terminal date, and $\dot{x}_{3}$ - $\dot{x}_{2}$. In contrast to the futures warket interpretation, the asset is not in zero supply; and if 1 is correlated across customers, then the aggregate endowment of the asset relevant for market clearing at each date $t$ will be affected by 1 .

Under elther Interpretation we assume that at times $t-1,2$ the customer chooses asset holdings $\dot{x}_{t}$, and a risk-free asset position $B_{t}$ to maxialze the expected utility of terminal (i.e., date-3) wealth

$$
\text { E } U\left(w_{3}\right)
$$

subject to

$$
\begin{gathered}
w_{3}-B_{2}+\dot{x}_{3} \bar{P}_{3} \\
\bar{P}_{2} \dot{x}_{2}+B_{2}-W_{2}-B_{1}+\bar{P}_{2} \dot{x}_{1} \\
P_{1} \dot{x}_{1}+B_{1}-w_{1}-P_{1} 1_{1}+w_{0} .
\end{gathered}
$$

where $1_{1}$ represents the Initial endowent of the asset and $w_{0}$ represents other wealth. Note that:

$1_{1}-0$ and $\bar{x}_{3}-\bar{x}_{2}+1$ in the futures market case;

$1_{1}-1$ and $\dot{x}_{3}-\dot{x}_{2}$ in the stock market case.

If $B_{1}$ and $B_{2}$ are eliminated fron $(2 a)-(2 c)$ we obtain

$$
w_{3}-w_{0}+\left(\tilde{p}_{2}-\bar{p}_{1}\right)\left(\bar{x}_{1}-1_{1}\right)+\left(\tilde{P}_{3}-\tilde{p}_{2}\right)\left(\bar{x}_{2}-1_{1}\right)+\bar{p}_{3} 1
$$


where $\dot{x}_{t}-1_{1}$ represents the excess deand for the asset, whether it be a futures contract or a stock. Therefore, It simplifles matters to define a Erader's excess demand to be

$$
x_{t}-\dot{x}_{t} \cdot 1_{1} \quad t=1,2 .
$$

In the above notation customers choose their positions to maximize

$$
E U\left(W_{3}\right)-E U\left(W_{0}+\left(\bar{P}_{2}-P_{1}\right) x_{1}+\left(\bar{P}_{3}-\bar{P}_{2}\right) x_{2}+\bar{P}_{3} 1\right) .
$$

We w1ll assume that $\bar{p}$ is nornally distributed at each date, and that

$$
U(W)=-e^{-w W}
$$

By backward Induction, and (4). If we let $x_{2}^{c d}$ denote the optimal value of $x_{2}$ (chosen at date 2 ) then $x_{2}^{c d}$ solves

$$
\max _{x_{2}} E_{2} U\left(W_{2}-P_{2} 1_{1}+\left(\bar{P}_{3}-P_{2}\right) x_{2}+\bar{p}_{3} 1\right)
$$

Using the exponential utility function, the optimal value for $x_{2}$ is

$$
x_{2}^{c d}-\frac{E_{2} P_{3}-P_{2}}{a \operatorname{Var}_{2} \bar{B}_{3}}-1
$$

where all means and varlances are conditioned on the information at time 2. Note that the customer's excess demand is $x_{2}^{c d}$ which is IInear in 1 . Hence, If all custoners are identical, except possibly with respect to 1. we can take $x_{2}^{c d}$ to represent the aggregate demand of customers, and 1 to be the aggregate potential Imbalance.

We assume that there are $M$ other traders in the market who do not hold the spot commodity and thus face no spot price risk; these are the market makers. (Under the stock market Interpretation, assume that the market makers do not hold an endowment of the securlty prior to thelr date 1 
trading with outside customers.) Market makers have the same utility function, but for then 1 - 0 . Hence, if the excess demand per warket maker is $x_{2}^{\text {md }}$ the total excess demand by market makers in period 2 is

$$
M x_{2}^{m d}-M \frac{E_{2} \tilde{P}_{3} \cdot P_{2}}{\operatorname{Var}_{2} \bar{P}_{3}}
$$

We now state the assumption critical to understanding the benefits of walting frou perlod 1 to perlod 2 to trade. In particular, it is that arynchrontzation of deslred trades creates the demand for Immediacy at time 1. Thus, the positive immediacy denand felt by the customers at time 1 is, by definition, offset by nes custoners arriving at date 2 with the opposite Imbalance from those who arrived at date 1. Their aggregate excess demand $1 s$

$$
\frac{E_{2} P_{3}-\bar{P}_{2}}{\operatorname{Var}_{2} \bar{P}_{3}}+1
$$

Market clearing at date 2 requires that the excess demand of (a) customers who arrived at date 1 , plus (b) market makers, plus (c) the new customers arriving at date 2 should sum to zero:

$$
\frac{E_{2} \bar{P}_{3}-P_{2}}{\operatorname{Var}_{2} \bar{P}_{3}}-1+M \frac{\left(E_{2} \bar{P}_{3}-P_{2}\right)}{-\operatorname{Var}_{2} \bar{B}_{3}}+\frac{E_{2} \bar{P}_{3}-P_{2}}{\operatorname{Var}_{2} \bar{P}_{3}}+1-0 .
$$

Note that in a Eutures interpretation. the right-hand side represents an aggregete endoweent of zero, while In a stock market (7) means that excess demands (1.e.. trades net of endownents) must sun to zero. Note also that under our convention that perlod 3 is merely a terainal condition. (7) Lopl1es:

$$
E_{2} \mathbb{P}_{3}-P_{2}-0 \text {. }
$$


The equilibriun excess demand at date 2 of the customer arriving at the market at date 1 is thus

$$
x_{2}^{c d}=-1
$$

Using (3), (4), (8), and (9) we can find the date 1 deaand of the customer from

$$
\operatorname{Max}_{x_{1}} E_{1} U\left(W_{0}+x_{1}\left(E_{2} \bar{P}_{3} \cdot P_{1}\right)+1 E_{2} \bar{P}_{3}\right)
$$

Th1s problem has the same form as the problea in perlod 2 except that the risk frov the polnt of view of period 1 is that $P_{2}-E_{2} \bar{P}_{3}$ is not known. As before. the customer's excess demand function is

$$
x_{1}^{c d}-\frac{E_{1} \bar{P}_{3}-P_{1}}{\operatorname{var}_{1}\left(E_{2} \bar{P}_{3}\right)}-i
$$

where the law of lterated expectations is used to obtain $E_{1} E_{2} \bar{P}_{3}-E_{1} \bar{p}_{3}$.

Market Makers and the Provision of Immediacy

At date 1 , there are $M$ market makers. They constantly watch the floor of the exchange elther directly or through thelr agents on the floor. They solve the same maximization problen as the customers except that for them 1 - 0 . Hence thelr excess deand function is

$$
x_{1}^{n}-\frac{E_{1} \bar{p}_{3} \cdot P_{1}}{\operatorname{var}_{1}\left(E_{2} P_{3}\right)}
$$

Market clearing at date 1 thus requires

$$
M x_{1}^{a}+x_{1}^{c d}=0
$$

Using (11) and (12), it is seen that (13) becomes: 


$$
\frac{E_{1} \bar{P}_{3}-P_{1}}{\operatorname{Var}_{1}\left(E_{2} \bar{P}_{3}\right)}-\frac{1}{1+M} \text {. }
$$

Let $\overline{\mathbf{r}}-\overline{\mathrm{P}}_{2} / \mathrm{P}_{1}-1$, be the excess return earned by the market makers. Then

$$
E_{1} \bar{r}-\frac{P_{1} 1}{1+M} \& \operatorname{Var}_{1}(\tilde{r})
$$

Thus if $M$ is finite, a positive value of $P_{1} I$ (which causes hedgers to desire to "short") will induce a temporary fall in the market price. Note that we have defined the order Imbalance to sun to zero across perlods 1 and 2. In particular, no aggregate risk is associated with holding the asset across periods. Therefore, in the absence of an asynchronization of order flows, $E_{1} \bar{r}-0$. It is the asynchronization of these flows and the finite risk bearing capacity of market makers that leads $E_{1} \bar{r}$ to deviate frod 0 . Note that from (12) and (14) the value of the positions held by a typlcal market maker (1.e., his inventory) is

$$
P_{1} x_{1}^{n}=\frac{P_{1}}{1+M} \text {. }
$$

The larger is this inventory the higher the expected return between period 1 and 2 to compensate the aarket maker for the risk that new information may arrive (causing $E_{2} \vec{P}_{3}-P_{2}-P_{1}$ ) leading to capltal losses on the inventory positions.

\section{Deteminetion of the Number of Market Makers}

A aarket aaker choosing always to have a prasence on the trading floor 1s assuned to forego opportunities elsewhere worth \$c. The gain frod boing on the floor 1s the ablilty to trade at price $P_{1}$. Then the expected utility of a market naker who pays \$c out of Initial wealth 1s 


$$
E U\left(W_{0}-c+\left(\bar{P}_{2}-\bar{P}_{1}\right) x_{1}^{\mathbb{W}}\right)
$$

where the profit between period 2 and period $3,\left(\bar{P}_{3}-P_{2}\right) x_{2}^{m}$ does not appear because (6) and (8) imply that $x_{2}^{m}-0$

Free entry of market makers will occur until

$$
E U\left(w_{0}-c+\left(\bar{P}_{2}-P_{1}\right) x_{1}^{m}\right)-E U\left(W_{0}\right)
$$

Equation (12) and the exponential utility assumption can be used to evaluate (16):

$$
e^{a c} \varepsilon \exp \left(-\left(\frac{a^{2}}{2}\right)\left(\operatorname{Var}_{1} \bar{P}_{2}\right)\left(\frac{1}{1+M}\right)^{2}\right)-1
$$

or

$$
\begin{aligned}
& e^{a c} \varepsilon \exp \left(-\frac{t}{2} z^{2}\right)-1 \text {, where } \\
& \tau-a^{2} \frac{\operatorname{Var} 1 \bar{p}_{2}}{(1+M)^{2}} \operatorname{Var} 1 \quad z^{2}-\frac{1^{2}}{\operatorname{Var} 1}
\end{aligned}
$$

Using the moment generating function of the non-central Chi-squared distribution (17b) becomes

$$
\frac{1}{\sqrt{1+t}} \exp \left(\frac{\cdot(E 1)^{2}}{1+t}\left(\frac{t}{2}\right)\right)-e^{-a c} .
$$

If we assume that the expectation of an order imbalance is zero, 1.e.,

$E 1$ - 0 , then (18) becomes

$$
\frac{1}{\sqrt{1+t}}-e^{-a c}
$$

Equation (19) implies that

$$
t-a^{2} \frac{\left(\operatorname{Var}_{1} \bar{P}_{2}\right) \operatorname{Var} 1}{(1+M)^{2}}
$$


is deternined solely by ac and is an increasing function of ac. The lower the cost of malntalning a market presence, the greater the number of market makers in equilibriun. That number would also be larger, of course, the smaller the risk-aversion parameter a for the market makers.

Var 1 is the average size of hedging demand (since hedging demand in Its average size is $E|1|$ whlch is proportional to Var 1 when $I$ is normally distributed). $\operatorname{Var}_{1} \overline{\mathrm{P}}_{2}$ is the predictability of the price change. Hence, as elther of these two variances rises the number of market makers rises.

\section{Some Empirlcal Implications of the Model}

The contribution of market makers shows up in the correlation between successive price changes. Since the model is only a 3 -perlod model with a single liquidity event at time 1 , we define the correlation to be

$$
q-\frac{\operatorname{Cov}\left(P_{2}-P_{1}, P_{1}-E_{0} P_{1}\right)}{\sqrt{\operatorname{Var}\left(P_{2}-P_{1}\right) \operatorname{Var}\left(P_{1}-E_{0} P_{1}\right)}} .
$$

Ising (14), the fact that $P_{2}-E_{2} \bar{P}_{3} \cdot E_{0} \bar{P}_{1}-E_{0} \bar{P}_{2}$ and $E_{1} \bar{P}_{2}-E_{1} \bar{P}_{3}$ ylelds

$$
\begin{aligned}
& P_{2} \cdot P_{1}-P_{2} \cdot E_{1} \bar{P}_{2}+\frac{1}{1+M}=\operatorname{Var}_{1}\left(\bar{P}_{2}\right) \\
& P_{1}-E_{0} P_{1}-E_{1} \bar{P}_{2}-E_{0} \bar{P}_{2}-\frac{1}{1+M} a \operatorname{Var}_{1}\left(\bar{P}_{2}\right) .
\end{aligned}
$$

To lopert a timeless quality to the uncertalnty, assume that one-step-ahead varlances are the same at each date, 1.e.,

$$
s^{2}-\operatorname{Var}_{1}\left(\bar{P}_{2} \cdot E_{1} \bar{P}_{2}\right)-\operatorname{Var}\left(E_{1} \bar{P}_{2}-E_{0} \bar{P}_{2}\right)-\operatorname{Var}_{1}\left(\bar{P}_{2}\right)
$$

We can now restate $q$ : 


$$
q-\cdot \frac{t}{1+t} \text {. }
$$

Thus, from (19) the correlation between successive price changes is negative and is determined solely by the cost of being a market maker $c$.

Note that the covariance between successive price changes is

$$
\operatorname{Cov}\left(\widetilde{P}_{2} \cdot P_{1}, \bar{P}_{1}-E_{0} \bar{P}_{1}\right)-\frac{a^{2} \operatorname{Var} 1}{(1+M)^{2}} s^{4}-i s^{2} .
$$

Hence, for a given $c$, since $t$ is fixed, assets with more variability of expected price changes will have higher negative covarlance.

Finally, consider the amount of immediacy provided in equilibrius. This can be measured by the amount of customer trade that is completed in period 1, $x_{1}^{c d}$, and the amount completed in perlod $2, x_{2}^{c d}-x_{1}^{c d}$, which can be derived from (11)-(14):

$$
\begin{aligned}
& x_{1}^{c d}-\frac{M}{1+M} 1 \\
& x_{2}^{c d} \cdot x_{1}^{c d}-\frac{1}{1+M} .
\end{aligned}
$$

Since the total size of the trade desired is -1 , the fraction completed in perlod $I$ is deternined by $M$. When $M$ is very large the transaction is completed Imediately and the aarket can be sald to be liquid.

\section{Extenstons and Apolications}

Many readers will have been surprised to have come so far in a paper on aarket liquidity with no reference to the term "bld-ask spread." That tern has Indeed dominated acadenfc discussions of transaction costs and aarket efficlency ever since the ploneering paper by Demsetz (1968); and, even before that, the tern was the standard, short-hand among practitloners for contrasting the cost of trading between markets and over tine. For all lts 
fanlilarity, however, and Its rough comnon sense as a metric, we belleve it does not fully capture the notion of market liquidity.

Limtertions of the bid-ask spread as measure of liquidity

First (as Stoll (1976), (1984) has emphasized), the bld-ask spread neasures exactly the market maker's return for providing immediacy only in the special case in which the market naker simultaneously "crosses" (1.e.. executes both sides of) the trade, one at the bid and the other at the ask. But in that case, of course, the spread could not also serve as a valld measure of the cost of supplying lmmedlacy to each of the customers. It is simply a charge by the market maker for executing their orders, rather than for providing them liquidity services.

In the more typlcal case that our model was designed to portray, the orders do not arrive simultaneously but are randomly separated in time. If so, the price may change between the time at which the market maker buys and sells; and the market maker may earn much more or less than the spread quoted th the time of the first leg of the transaction. And, for the same reason, the currently quoted spread cannot serve any transactor as a precise measure of the cost of trading lmmediately rather than delaying the order, particularly when the order is a large one. Yet that cost, as we have emphasized, is the essence of market liquidity. A customer desiring to sell 1s I1kely to be nore concerned with how the bld will change over the than with the slze of the current bid-ask spread.

The benefit of lmadiacy to a customer is the shedding of the price risk assoclated with walting. In most real-world exchanges thls walting can also be achleved by means of a "llalt order" to sell, for example, at the current quoted bid price. Such a Ilolt order will be executed if and when a buyer 
wllling to pay this price appears and no other seller is offering to sell at a lower prlce. But that may never occur and the customer may have to revise the order and sell at a a price lower than the bid price at the time the first limlt order was sent in. Thus, If lucky, the limit-order customer gets a price higher than the bid, whlle if unlucky, a lower price. The customer's cholce between 1 inlt orders and market orders is thus governed not by the bld-ask spread, but precisely by those considerations which our model suggests determine the supply and demand for immediacy, 1.e. by the likel thood that a buyer will arrive who is willing to pay wore than the current bid. (See Cohen, et al. (1981), for an equllibrlum analysis of bidask spreads which emphasizes the importance of jumps in the price away fron the current quotes.)

Note also that a substantial volume of eransactions occur within the prevalling quoted bid-ask spread because the traders who comnit to a bid (or ask) are giving the market an option. Some traders may decide not to commit to buylng or selling at particular prices and thus the quoted bld way be lower than the actual bids whlch appear in response to a market sell order. The more that market orders to buy and sell are separated in time the greater the exposure of the market maker to the risks of adverse Information trading. The bid-ask spread, In addition to the pure timing option prealum, w111 then contain sel11 another component, which compensates the market makers on their Information-less trades for thelr likely losses to the Informed traders. Thls phenomenon, as noted earlier, has been much studled In the acadenic literature on narket alcro structure. (See, e.g., Glosten and Milgrou (1985).) Much less attention, however, has been directed to the Inverse problem of whet is likely to happen to conventional quoted bid-ask 
spreads in highly active markets. Ilke futures markets, where many separate buy and sell orders are entering the trading pit virtually simultaneously. Because the adverse selection problem arises only when a market maker cannot hope to offset a position lmadiately, and because the costs of maintalning a market presence are mainly (and, in our model, entirely) fixed costs, it might seen that quoted bid-ask spreads and market makers' profits from what amounts to crossing trades would be driven towards zero by the competitive entry of new warket makers. ${ }^{1}$ Where the flxed costs are large relative to the entry-Inhlbiting trading risks, a competitive market may not be viable because the market makers would have no way of recovering their fixed costs of malntaining a presence on the floor. ${ }^{2}$ To keep markets viable, therefore, exchanges may linit the number of "seats" avallable to market makers (or designate a regulated specialist).

Exchanges also typically define a minimum price change unit (called a "tick") which, in highly active markets, serves also to set a minimum on both the quoted bid-ask spread and the profits a "scalper" makes from a quick $\therefore$ naround. This somewhat subtle and frequently overlooked role of the alnimum tick helps explain, among other things, the seeming paradox of finding many traders in an obviously highly competitive pit fighting (sometimes literally) to execute an order. This behavior suggests that the quoted bid-ask spread of one tick, and hence the profit fron a quick turn on

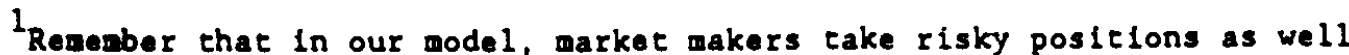
as aatch orders. Entry occui's to the point where the market makers earn a return on their risky positions plus any profits from simultaneous matching which fust balances the trading risks and the flxed costs of maintaining a continuous presence.

2 In terms of the notation in our model, the non-viability of a competitive equilibrium would occur when $c$ becomes large relative to a. 
- standard size trade is actually higher In an active market than lt would be In the absence of the minlmum tick rule. Part of the art of managing a futures exchange is finding a minlmum tick slze for lts contracts, high enough to sustain a viably competitive supply of floor traders, but not so high as to glve rlse to the problems of rationing and queue discipline so often encountered under prlce controls. 1

Limitations of the "Liquidity Rat10" as a Measure of Market Liquld 15y Another widely used emplrical messure in inter-market comparlsons of market 11 quidity is the "liquidity ratio," defined as the ratio of average dollar volume of trading to the average price change during some Interval. (See, e.8., Dubofsky and Groth (1984), Cooper, Groth and Avers (1983), Re111y and Wong (1982) and Martin (1975).) A high value for the ratio is taken to Indicate that many shares were traded with little price change; and a low value to suggest that a trader bringing a large block to market will Induce a large adverse price change.

These measures, of course, tell us at best only about past average associatlons between price changes and volume. They do not answer the critical question of how the sudden arrival of a lerger-than-average order would affect price. Nor do they distingulsh adequately among the sources of price volat1lity. A particular market may display high price varlabillty not because it is 1111 quid but because new fundamental information arrives

$1_{A}$ closely related but somewhat different problen is faced by the designers of computerized, automat1c execution systens 11ke the wuchpubliclzed (but iltele used) INTEX exchenge in Berruda. Because the users can hit directly any bids or offers showling on the screen, no internediary can hope to earn a Ilving by "scalping" the bid-ask spread on quick trades. This keops narket makers, who alght otherwlse provide lmediacy when orders do not netch, fros being able to recover thelr opportuntty costs of anintalning a continuous presence in the market. 
frequently. High price volatility can occur without high volumes of trading: In fact, when the Import of the news is unamblguous, there may be no trading at all.

The liquidity ratio, In sun, falls to capture what we have called the immediacy that the market's structure offers. At best, and with all due regard for the plefalls of estimating simuleaneous equations, It wighe hope to measure the average elasticley of the market's demand curve for transactions. What we need, however, is a measure of how well the market makers are providing customers with an effective substitute for the delays in a search for a more inclusive set of counterparties. Whether so complex a notion can ever be distilled down to a single scalar is still far frod clear. our equations (24) and (25) (a) and (b) with thelr focus on reversals offer some proulsing new leads (simllar in spirit to those opened earlier by Roll (1984)), which we hope to follow up in future emplrical research.

The need for new ways of measuring and comparing the llquidity of different market structures takes on added urgency in the light of the dramatic stock-market events of last October and especlally of the many policy proposals for market reform that have surfaced in the wake of the crash and are now being actively debated in the press and in Congress. But even in the absence of numerical calibrations of liquidity we belleve that the wodel of aarket liquidity presented in the previous section can offer a helpful perspective on the main events of those hectic days.

\section{Market Liquidity and the Crash of October 1987}

We hasten to add that our interpretation of the recent crash in terms of our nodel of market liquidley must not be taken as signifying our bellef that the event was entirely, or even primarily, a matcer of liquidity racher than of fundamentals. (See Miller, et al. (1987) for a discussion of the events 
preceding and surrounding the crash.) Whatever the precipleating cause, a massive liquidity event, in our earlier sense of an lmbalance in the demand for Immediacy clearly occurred at the opening of the markets on the 19 th. Both the futures market and the cash spot market were hit simultaneously with a flood of sell orders of unprecedented size.

Each of the two markets responded immediacely to the Imbalances, but in ways appropriate to their characteristic and, as we had noted earlier, quite different structures. The rules of the NYSE pernit-.indeed, encourage.specialists to delay the opening of trading when the overnight accumulation of orders for a particular stock is too far out of balance to allow market clearling at a price near the previous close. The delayed opening gives the specialist tine to search the floor and the upstalrs block-trading desks for balancing orders on the other side. Under ordinary conditions, when most other stocks have opened and are trading normally, that search is completed successfully, and trading resumed (though, typlcally, with a somewhat larger than usual price gap) in a matter of a few minutes. At the opening of the 19 th, however, the order Imbalances were so widespread and so large that no Imediate help from on or off the floor was avallable to the beleaguered specialists of many of the nost heavily traded shares. An hour after the opening bell, nore than a third of the stocks in the Dow-Jones Index (Including such widely-followed international companies as IBM, Sears and Exxon) had yet to start trading.

By contrast, the S\&P 500 futures market at the Chicago Mercantile Exchange, like other futures markets, seeks to provide a setting in which prices can best speedily reflect the best current information. If the outcry at the opening call on a futures exchange shows the overnight accumulation of orders to be heavily unbalanced, then the price will junp directly to a level 
at which erading can imediacely take place. I The previous closing price plays no explicit role in seteing that level or the path to reach it. This contrast in opening procedures between the futures and the stock markets is fully understandable in the Ilght of our model. The high risk assoclated with futures trading (recall pages 4.6 above) causes those markets to be organized precisely to provide maximal immediacy of order execution. The costs of delayed execution being normally less for stock trading, the market makers there seek to provide more search service relative to imediacy than In the futures markets.

On Monday the 19th, opening prices in New York had to fall some 10 percent below the Friday close--an enormous gap by past standards--before trading in all scocks could begin. 2 By 11:00 A.M. or so, New York time, however, all the major delayed-opening scocks had resumed crading, and the two markets were now virtually back in step. Although the price fall had been large, the two markets, from all outward appearances appeared to have handled successfully the enormous Imbalance of sell orders that had accumulated at we opening. But the capltal resources of thelr regular market makers on or around the floor had by then been heavily commleted. In Chicago, many of the swaller warket makers had left the floor, elther voluntarlly or under

1 The Chicago Boerd of Options Exchange opens with an auctoneer escablishing provisional opening prices for each traded option. But with so many separace nacurities and striking prices involved, the process of finding simultaneous, viable crading ranges is far from easy when prices are moving rapidly. On the morning of the $19 \mathrm{ch}$, and again on the $20 \mathrm{ch}$, by the time the "rotation," as the opening process is called, had worked 1 ts way around to the last series, the earlier, cencatively-escablished trading ranges had become hopelessiy wide of the mark. The process had to be repeated and on ruesday trading did not in fact begin until far after the regular opening time.

2 This difference in opening procedures in the two markets undoubtedly contributed to the widespread (but nisleading) Impression at the time that the futures market in Chicago, if not acturliy dragging down stock prices in New York, was at least slgnaliing to an already panicky public that heavy new selling pressure was on les way to the narket in New York. 
pressure from their clearing firms. Those that remelned were unwilling to take on large positions in such a volatile market except at price concessions far larger than normal. When a further wave of sell orders hlt both markets somewhat after noon, New York time, there was less resistance from the market makers and the fabled "meltdown" was soon under way. Or, to use the less colorful language of our model, both markets had by then become highly 11liquid and virtually Incapable of supplying Immediacy at the low cost their users in the past had come to expect.

That 111 lquidity was evidenced in the spot market by (1) the virtual impossibllity of executing market sell orders at the bld quoted at the time of order entry, and (2) the delays in executing and conflrwing trades on Monday afternoon and again, after the opening on Tuesday. ${ }^{1}$ on the futures exchange, order flows that might have moved the market by at most a tick or two In the week before, were moving the market by 10 or 20 times that amount or more in the early afternoon of Tuesday, October 20. Desplte the evident rise in the cost of Immediacy to sellers, the inflow of sell orders continued, and perhaps even accelerated in what took on all the appearances of a classic, self-reinforcing panic. By early afternoon on Tuesday, trading had been suspended in many NYSE stocks and in the main optlons and futures markets. With virtually no market-making capacity remaining, the burden of equilibration had to be assumed by the search for buyers off the market, culminating in the cavalry-like ride to the rescue on Tuesday afternoon by large U.S. corporations instituting buy-back programs of thelr own shares.

In the case of the NASDAQ bulletin board, market prices were sometimes changing at a faster rate than the quotes were belng updated. When the best offer to sell is entered below the best bid to buy, a market is deemed crossed and under the then standing NASDAQ rules only the bid showed on the screen. No further transactions could be ade until the obsolete bid was updated which often involved substantial delay. 
At the same time, the Federal Reserve Systen was directly and Indirectly encouraging banks to support dealer inventory positions. By the end of the day, these infusions of buying power had pushed prices nearly back to their levels before the Monday noon collapse and substantlal market-making capacity was back in place.

Effective market-making capacity in the perlod immediately after the crash, however, as well as at several critical junctures during the crash, was reduced by restrictions imposed on "program trading" which cut the normal arbltrage linkage between the warket makers in the spot and futures markets. Arbleragers, by taking offsetting positions in both markets close to simultaneously, can transmit some of the pressure of order imbalances from the market first impacted to the market makers in the other. Market makers' resources in both warkets can thus be brought to bear on the initiating Imbalance more effectively, much as they would be if the number of active market makers had been increased. Price concessions and hence the cost of transacting can be kept smaller in both markets, thanks to arbitrage program trading, than might otherwlse be the case. 1 How Ironic then to find arbitrage progran erading still so often blamed for undermining investor confidence in the market.

IFor a further discussion of arblerage progran erading and especially its interaction with portfollo insurance, see Grossman (1988). 


\section{REFERENCES}

Amlhud, Y.; Ho, T.; and Schwartz, R. Market Making and the Changing Structure of the Securlties Industry. Lexington Books, 1985.

Cohen, K.; Malr, S.; Schwartz, R.; and Whitcomb, D. "Transaction Costs, Order Placement Strategy and the Existence of the BId-Ask Spread." Journal of Polfcical Economy 89 (April 1981).

Cooper, K.; Groth, J. C.; and Avers, W. E. "LIquidity, Exchange Listing, and Common Stock Performance." Texas ASY University, August 1983.

Demsetz, H. "The Cost of Transacting." Quarterly Journal of Econonics 82 (February 1968).

Dubofsky, F., and Groth, J. "Exchange Listing and Liquidity." Department of Finance, Texas A\&Y University, mimeo, Februsty 1984.

Glosten, Lawrence R., and M1lgrom, Paul R. "B1d, Ask and Transaction Prices In a Specialist Market with Heterogeneously Informed Traders." Journal of Financlal Economics 14, 1 (March 1985): 71-100.

Grossman, Sanford J., and M1ller, Merton H. "Economic Costs and Benefits of the Proposed One-Minute IIme Bracketing Regulation." Journal of Futures Markets vol. 6, No. 1 (Spring 1986b), pp. 141-66.

Grossman, Sanford J., and Miller, Merton H. "The Determinants of Market Liquidity." University of Chicago, July 1986a (manuscript).

Grossman, Sanford J. "An Analysis of the Implications for Stock and Futures Price Volatility of Program Trading and Dyramic Hedging Strategies." Journal of Business (1988), forthconing.

Ho, T. "Dealer Market Structure: A Dynanic Competitive Model." New York University working paper, March 1984. 
Martin, P. "Analysis of the Impact of Competitive Rates on the Liquidity of NYSE Stocks." Economic Staff Paper 75-3, Securities and Exchange Commission (July 1975).

Miller, Merton H., Chairman; Hawke Jr.. John D.: Malkiel, Burton; and Scholes, Myron. Preliminary Report of the Committee of Inoulicy Appointed by the Chicage Mercantile Exchange to Examine the Events Surrounding October 19, 1987 (Decenber 22, 1987.) Mimeo. 